\title{
Design, Construction and Testing of a Hybrid Photovoltaic (PV) Solar Dryer
}

\author{
JB Hussein ${ }^{1}$, MA Hassan ${ }^{2}$, SA Kareem ${ }^{3}$, KB Filli ${ }^{4}$ \\ ${ }^{1,4}$ Department of Food Science and Technology, Modibbo Adama University of Technology Yola, Nigeria \\ ${ }^{2}$ Department of Mechanical Engineering, Modibbo Adama University of Technology Yola, Nigeria \\ ${ }^{3}$ Department of Chemical Engineering, Modibbo Adama University of Technology Yola, Nigeria \\ ${ }^{4}$ Product Design and Perception, Agrifood and Bioscience - Research Institutes of Sweden (RISE) Gothenburg, Sweden
}

\begin{abstract}
A hybrid photovoltaic solar dryer was designed, constructed and tested in the Department of Food Science and Technology, Modibbo Adama University of Technology Yola, Nigeria. The thin layer drying behaviour of tomato slices using a hybrid drying method compared to solar and open sun drying was investigated. The dryer consists of solar collector, photovoltaic solar panel, battery and drying chamber. The dryer was operated as both a solar-energy dryer and as a hybrid solar dryer. The drying performance of the dryer was evaluated with fresh tomato slice and compared with open sun drying under the same climatic conditions. The dryer recorded a raised temperature of $62^{\circ} \mathrm{C}$ attainable in the drying chamber of hybrid dryer and $54^{\circ} \mathrm{C}$ attainable in the drying chamber of solar dryer. The moisture content of tomato slices was reduced from $94.22 \%$ wet basis to $10 \%$ in 6 hours for hybrid drying method while it took 9 hours to achieve the same moisture content reduction in the solar dryer. The average drying rate and the efficiency was computed as $0.0800 \mathrm{~kg} / \mathrm{h}$ and $71 \%$ for hybrid dryer and $0.0578 \mathrm{~kg} / \mathrm{h}$ and $65 \%$ for solar-energy dryer respectively. The quality of the tomato samples dried using the hybrid dryer was superior to those of solar and sun drying methods. From the result of this study it shows that a hybrid solar-energy dryer using photovoltaic ( $P V)$ solar panel suggested a promising process for adoption to preserve tomato which can prevent it from spoilage and post-harvest losses. The good quality and shelf stable dried tomato slices is indicative for a sustainable productivity that will create a sound avenue for economic growth in tomato producing regions of the world.
\end{abstract}

Keywords - design, hybrid dryer, photovoltaic solar panel, solar dryer and tomatoes.

\section{INTRODUCTION}

Drying traditionally using the sun is the oldest preservation technique of agricultural products worldwide which dates back to human civilization. To date, open sun drying is still widely used for preservation of agricultural products in the tropics and subtropical regions of the world. The traditional practice of open sun drying however has inherent limitations which includes; high crop losses due to inadequate drying to safe water activity, microbial/enzymic attacks as a result of longer drying time, insects, birds and rodents encroachment, unexpected weather changes without control and other effects environmental elements [1]. With such drawbacks of open sun drying, the adoption of solar-energy based dryers demonstrates increasingly more attractive and promising for applications as commercial propositions. Solar drying can simply be considered as an elaboration of sun drying, and it is an efficient system of utilizing solar energy [2]. As an alternative to open sun drying, solar energy dryers avail farmers with possibility of improved post-harvest management system that is sustainable for increased economic growth that will overcome most drawbacks of the traditional open sun drying systems by yielding products which is acceptable to both national and international standards[3,4]. In addition the solar drying systems have added advantages of savings in energy, time and space requirements during drying operations which add up to making the method not only more efficient but also more environmentally friendly without constituting any danger to the environment $[5,6]$. Solar energy for crop drying is environmentally friendly and economically viable in the developing countries of the world. It's also form a sustainable energy utilization that has a great potential for wide variety of applications because it is abundant and accessible, especially for countries located in the tropical region of the world like Nigeria. Solar-energy drying systems overcomes the drawbacks of traditional open sun drying such as, contamination from dust, insects, birds and animals, lack of control over drying conditions, possibility of chemical, enzymic, and microbial spoilage due to longer drying times [2,4]. Solar-energy drying offers an alternative which can be exploited to preserve vegetables and fruits in clean, hygienic and sanitary conditions that can be acceptable by the consumer. The process saves energy, time, occupies less drying area, improves product quality, makes the process more efficient and protects the environment $[1,5,6]$.

However, one significant disadvantage of solar-energy dryer is that it can only be used during the daytime when there is adequate solar radiation for conversion to heat. Solar dryers are constructed normally with no any form of back-up heating 
systems [7] and makes it difficult to use them for drying at nights or when there is no adequate sunshine. For commercial processors, this factor limits their ability to process a crop when there is no adequate sunshine; this limitation usually results in extended drying periods because drying can only occur during the day time when there is adequate solar radiation. This gap does not only limit productivity but results in an inferior product quality which does not encourage Agricultural productivity increase. For commercial processors, the ability to process continuously with reliability is important and crucial in order to satisfy and meet their markets demand. Most existing solar dryers are actually designed to operate only during the daytime and thus are constructed without any form of back up heating system [7]. A possibility of extending the process efficiency, in order to reduce the drying time and controlling the dependence of production cycle period on the weather would definitely be a welcome development, as this could lead to the improvement in both quality and quantity of processed products which can be more sustainable.

It then becomes expedient to consider innovative solutions for solar dryers that would have added advantage over the longer period of residence during drying, increase productivity and reliability through its ability to augment available heat during days with limited radiation as well as ability to operate during the night or during low sun radiation periods. Some hybrid dryers were developed to control the drying air conditions throughout the drying time independent of sun-shine especially at night or poor weather when it is not possible to use the solar energy, using alternative heating sources such as sawdust burner [8]; kerosene stove [9] or by using a biomass stove [10,11]; electric heater [12,13].

Grid-connected electricity and supplies of other non-renewable sources of energy are unavailable, unreliable, scarce or too expensive for many farmers and processors generally in most developing countries; this results in reduced expected profit as a result of inappropriate post-harvest processing [1]. It is therefore necessary to provide a solar-energy drying system with additional source of energy such as in the case of hybrid dryer (solar-energy dryer with energy storage system) to close the gap of continuous drying even when there is no solar radiation.

Based on the aforementioned fact, considerable studies on photovoltaic (PV) module to power dryers for forced convection air circulation have been reported among which are; [14] that developed a PV operated forced convection solar energy dryer; Barnwal and Tiwari (2008) [15] reported a hybrid solar grain dryer with a PV - driven DC fan which was used to dry maize [16] and also designed, analysed and evaluated a forced convection photovoltaic solar dryer which was used to dry plantain chips.

There is little information to our knowledge regarding the design of a hybrid photovoltaic solar dryer meant for the drying of fruits and vegetables such as tomato slice. The objective of this study was to develop a hybrid photovoltaic solar dryer with an energy storage system so as to improve the drying efficiency by reducing the drying time of tomato slices.

\section{MATERIALS AND METHODS}

\subsection{Components of the hybrid dryer and materials used}

The main components of the hybrid dryer are; drying chamber, rack and trays, heater, fan/blower, solar panel, solar battery and control panel. The materials used for the construction were; mild steel, galvanized steel and wire, plywood, solar panel, solar battery, on and off switch and thermostat (thermocouple). The drying chamber had a volume of $0.300 \mathrm{~m}^{3}$ constructed with galvanized steel. It was painted in silver colour inorder to reduce heat loss by radiation. The chamber was also enclosed by an outer chamber of $0.432 \mathrm{~m}^{3}$ volume made from the same material with the space between the two volumes filled with insulation material so as to reduce conductive heat loss. The insulation materials used was packed wool fiber of $0.050 \mathrm{~m}$ thick was used as the insulating material to achieve a minimal heat loss of 5\% from the drying chamber. The rack was constructed with mild steel and positioned in such a way that it allows easy insertion of individual trays at a distance of $0.1 \mathrm{~m}$ apart. The trays were constructed with plywood and its base was made of fine wire gauze which allows for heated air circulation and to pass through the tomatoes being dried.

\subsection{Design Consideration and Specifications}

The following determinant factors and assumptions were taken into consideration when constructing the hybrid dryer based on the procedures described by $[16,4]$;

$>$ Geographical and meteorological data of location.

$>$ The solar radiation of the location (Yola, Nigeria) as a case study was used as starting points in solar equipment design.

$>$ Sanitary design factors: the construction materials must be noncorrosive and nontoxic. 
Ease of assembly and disassembly: the hybrid dryer was constructed in such a way that all the surfaces contacting the drying samples can be exposed, clean and inspect. Easy to adjust, dismantle and couple.

Time constraint.

$>$ The initial and expected final moisture content of the vegetables and fruits to be processed.

$>$ The ambient temperature and operating in-chamber temperature.

Having considered and analysed the above listed factors with specific reference to the case study location Yola, the following design specifications were arrived at;

$>$ Use tomatoes as a case study vegetable so as to cover a large range of fruits and vegetables. Also, tomatoes are vegetables of high interest in the study area as being widely grown and having a very high percentage of post-harvest loss due to inadequate post-harvest processing in the study area.

$>$ The required thermal performance was identified.

$>$ Based on the expected capacity of the dryer, economic considerations and engineering and ergonomic factors considerations, the shape and size of the dryer and its components were analysed and a cabinet-type dryer was chosen as the most optional.

$>$ Initial moisture content: $95 \%$ wet basis.

$>$ Expected moisture content: $10 \%$ wet basis.

$>$ Operating temperatures: ambient was $30^{\circ} \mathrm{C}$ and in-chamber was $60^{\circ} \mathrm{C}$.

$>$ Residency period per batch: 8 Hours.

$>$ Heat loss from drying chamber $\leq 5 \%$.

\subsection{Design calculations}

\subsubsection{The heater design}

\section{A. Amount of moisture removed}

The amount of moisture removed from a given quantity of wet tomatoes slices to bring the moisture content to a safe storage level in a specified time was calculated using the following equation described by [17].

$$
M_{w}=M_{p}\left(M_{i}-M_{f}\right) /\left(100-M_{f}\right)
$$

Where; $M_{p}=$ Initial mass of the tomatoes $(\mathrm{kg})$

$$
\begin{aligned}
& M_{i}=\text { Initial moisture content (\% wet basis) } \\
& M_{f}=\text { Final moisture content (\% wet basis) }
\end{aligned}
$$

\section{B. Quantity of heat required to remove the moisture (Ea) in KJ}

The quantity of heat required to evaporate the moisture was calculated as follow;

Quantity of heat required to evaporate the moisture $=$ heat energy to raise the temperature to $60^{\circ} \mathrm{C}+$ latent heat to remove moisture

$$
E_{a}=M_{p} \times C_{T} x \Delta T+M_{w} L_{v}
$$

Where; $C_{T}=$ Specific heat capacity of tomatoes $(3.676 \mathrm{KJ} / \mathrm{kgK})$

$\Delta T=$ Change in temperature of the drying chamber $30^{\circ} \mathrm{C}$ to $60^{\circ} \mathrm{C}$

$L_{v}=$ Latent heat of vapourization of water at s.t.p $2257 \mathrm{KJ} / \mathrm{kg}$

\section{C. $\quad$ Power $=$ Quantity of heat $/$ time (sec)}

$$
\text { Power }=E_{a} / t_{d}
$$


Where; $t_{d}=$ time of drying 8 hours

Based on the above calculations, a heating coil element of $0.5 \mathrm{KW}$ power was chosen for use.

\subsubsection{The fan/blower design}

\section{A. Mass flow rate of air $(\mathrm{kg} / \mathrm{s})$}

The mass flow rate $M a$ (in $\mathrm{kg} / \mathrm{sec}$ ) of the air was given as

$$
M_{a}=E_{a} / C_{p a} \times \Delta T \times t_{d}
$$

Where; $E_{a}=$ the quantity of heat required to evaporate the $\mathrm{H}_{2} \mathrm{O}$

$$
\begin{aligned}
& C_{p a}=\text { Specific heat capacity of air }(1.005 \mathrm{KJ} / \mathrm{kgK}) \\
& \left.t_{d}=\text { Theoretical time taken for drying ( } 8 \text { hours }\right)
\end{aligned}
$$

\section{B. Volumetric flow rate $\mathrm{Va}\left(\mathrm{m}^{3} / \mathrm{s}\right)$}

$$
V_{a}=M_{a} / \rho_{a}
$$

Where; $\rho_{a}=$ density of air at $60^{\circ} \mathrm{C}=1.2754 \mathrm{~kg} / \mathrm{m}^{3}$

Converting the value of the discharge obtained to cubic foot per min (cfm) for standard fan selection, we have [18];

$$
\begin{aligned}
& 1 \mathrm{cfm}=4.91747 \times 10^{-4} \mathrm{~m}^{3} / \mathrm{s} \\
& 0.00808 \mathrm{~m}^{3} / \mathrm{s}=16.4229 \mathrm{cfm} \\
& \text { Fan horse power }=(\text { Air flow } x \text { static presure }) /(6320 \times \text { fan efficiency })
\end{aligned}
$$

From literature, most industrial fans have efficiency ranging from 70-85\% as described by [19].

Using an efficiency of $85 \%$

Based on the above calculations and to ensure proper distribution of air to the drying chamber and for effective heat distribution, an axial flow fan with $0.02 \mathrm{Hp}$ and $110 \mathrm{~mm}$ of water static pressure was used.

\subsubsection{Total energy required}

The total energy required for drying is given as [20];

$$
E=M_{a}\left(H_{2}-H_{1}\right)
$$

Where; $\mathrm{M}_{\mathrm{a}}=$ mass flow rate of air, $\mathrm{kg} / \mathrm{sec}$

$\mathrm{H}_{2}=$ Enthalpy of warm air, $\mathrm{KJ} / \mathrm{kg}$ dry air

$\mathrm{H}_{1}=$ Enthalpy of ambient air, $\mathrm{KJ} / \mathrm{kg}$ dry air

Enthalpy of the air can be calculated using [20];

$$
H=1006.9 T+H_{r}(2512131.0+1552.4 T)
$$

Where; $\mathrm{Hr}=$ Humidity ratio, $\mathrm{Kg} \mathrm{H}_{2} \mathrm{O} / \mathrm{Kg}$ dry air (from psychometric chart)

$\mathrm{T}=$ air temperature, ${ }^{\circ} \mathrm{C}$

\subsubsection{The solar thermal collector design}

\section{A. The solar collect area (Ac) in $\mathbf{m}^{2}$}

The solar collect area $(A C)$ was calculated from the following equation as given by [21].

$$
A_{c}=\frac{V_{a} \times \rho_{a} \times \Delta T \times C_{p a}}{I \eta}
$$

Where;

I = Total global solar radiation on the horizontal surface during the drying period. The mean value of global radiation of Yola is given as $0.725 \mathrm{~W} / \mathrm{m}^{2}[22]$. 
$\eta=$ the collector efficiency, $30-50 \%[20]$.

Therefore, the collector area was $1.0345 \mathrm{~m}^{2}$. However, by making the collector width equal to $0.60 \mathrm{~m}$ to match the width of the dryer, the required collector length used was $1.7856 \mathrm{~m} \approx 1.80 \mathrm{~m}$.

\section{B. Absorber of the solar collector}

The solar absorber of the collector was constructed using $0.55 \mathrm{~mm}$ thick corrugated iron sheet, painted black and it was mounted in a box constructed of the same area. The absorber was implicit to be a perfect black body and so as to absorb greatest heat. Corrugated iron sheet was used because of its low cost, high melting point, inflammable and easily available in the local market.

\section{Covering material of the solar collector}

To create a greenhouse effect, a single layer transparent glass sheet of $5 \mathrm{~mm}$ thickness was placed on top of the absorber at a distance of $0.11 \mathrm{~m}$ apart. Glass was selected as glazing because it is easily available, has low cost, high value of transmittance for long and short wave radiations (80\%), not flammable and have high melting point. It also shelters the absorber from wind and allows solar radiation to reach the absorber.

\section{Solar thermal collector orientation and tilt angle}

The solar collector was tilted and oriented in such a way that it receives maximum solar radiation during operation. The best stationary orientation is due South in the northern hemisphere and due north in Southern hemisphere [23, 4]. The angle of tilt $(\beta)$ of the solar collector is given by the formula below [24, 25];

$$
\beta=10^{\circ}+\operatorname{Lat} \varnothing
$$

Where; Lat $\Phi=$ the latitude of the collector location $=7^{\circ}$ for Yola Adamawa state.

Therefore, solar collector in this work was oriented facing south and tilted at $17^{\circ}$ which is the best recommended orientation for stationary absorbers. This inclination also allow easy run off of water and enhance air circulation.

\subsubsection{Design of the drying chamber insulation}

Different materials are available for insulation but considering the availability and cost of insulating materials, wool fibers was used since it has thermal conductivity of $0.04 \mathrm{~W} / \mathrm{m}^{\circ} \mathrm{C}$ and can be favourably compared with other effective insulating materials such as glass wool [9]. Assumption of a loss of 5\% of the quantity of heat produced and the temperature of external part of drying chamber $30^{\circ} \mathrm{C}$ was made (Normal atmosphere temperature).

Heat transfer through the wall was by conduction hence Fourier's equation was relevant [18].

Quantity of heat lost per unit area $=\left(T_{1}-T_{2}\right) K_{1} / X_{1}$

$$
\begin{aligned}
& =\left(T_{2}-T_{3}\right) K_{2} / X_{2} \\
& =\left(T_{3}-T_{4}\right) K_{3} / X_{3} \\
& =U\left(T_{1}-T_{4}\right)
\end{aligned}
$$

Where; $\mathrm{K}_{1}$ and $\mathrm{K}_{3}=$ Heat transfer coefficient for mild steel i.e. $46 \mathrm{~W} / \mathrm{m}^{\circ} \mathrm{C}$

$\mathrm{K}_{2}=$ Heat transfer coefficient for wool fiber i.e. $0.04 \mathrm{~W} / \mathrm{m}^{\circ} \mathrm{C}$

$\mathrm{X}_{1}, \mathrm{X}_{2}$ and $\mathrm{X}_{3}=$ the respective thickness of mild steel and wool fiber

$\mathrm{U}=$ Overall heat transfer coefficient

$\mathrm{T}_{1}=$ Temperature of internal part of cabinet i.e. $60^{\circ} \mathrm{C}$

$\mathrm{T}_{4}=$ Temperature of external part of cabinet i.e. $30^{\circ} \mathrm{C}$

$\mathrm{X}_{1}=\mathrm{X}_{3}=0.0015 \mathrm{~m}$

\subsubsection{The solar panels with storage battery}

A PV system has to generate enough energy to cover the energy consumption of the loads and energy used by the system itself. The size and configuration of solar panel was then optimized in order to match the energy yield of the system with the energy consumption of the system. An estimate of the sizing of the panel and battery was made using the following design processes. 


\section{A. Determination of the total power consumption}

Prior to determination of power consumption, $12 \mathrm{~V}$ was used as the nominal operational voltage of the PV system, the total power rating of the dryer was around $600 \mathrm{~W}$ and the average daily operational time was 3 hours.

The daily energy requirement $(\mathrm{Wh})=600 \mathrm{~W} \times 3 \mathrm{~h}=1800 \mathrm{Wh}$

\section{B. Addition of system losses}

Some components of the PV system, such as charge regulator and battery use energy to perform their functions. Thus, we denote the energy used by the system as system energy losses. Therefore, the total energy requirement by loads, which was determined above was increase by a factor of $20 \%$ in order to compensate for the system losses.

$$
\text { Add system losses }=1800 \mathrm{Wh} \times 1.2=2160 \mathrm{Wh} / \text { day }
$$

\section{Sizing of the PV modules}

Different size of PV modules produce different amount of power. To find out the correct size of a PV module, the total peak watt produced needs was determined. The peak watt (Wp) produced depends on size of the PV module and climate of site location. Also we have to consider "panel generation factor" which is different in each site location and for Yola (Nigeria), the panel generation factor is 6.20 .

$$
\begin{aligned}
\text { Total peak watt }(W p) \text { of } P V \text { panel capcity needed } & =\frac{\text { total daily energy requirement }}{\text { panel generation factor }} \\
=\frac{2160}{6.20} & =348.3871 \mathrm{Wh} / \mathrm{day}
\end{aligned}
$$

Therefore, number of PV panels needed $=\frac{348.3871}{180}=1.94$ modules

So this dryer was powered by at least 2 modules of $180 \mathrm{Wp}$ PV modules.

\section{Determination of the battery size for recommended reserve time}

Batteries are a major component in the stand-alone PV systems. The batteries provide load operation at night or in combination with the PV modules during periods of limited sunlight. For a safe operation of the PV system one has to anticipate periods with cloudy weather and plan a reserve energy capacity stored in the batteries. This reserve capacity is referred to as PV system autonomy, which means a period of time that the system is not dependent on energy generated by PV modules, and is rated in days. For this design the autonomy of the system was taken as 24 hours (one day).

The Battery capacity required by the system $=$ the total DC energy required by loads $\times$ the number of days of recommended reserve time.

Therefore, the minimal capacity of the battery was determined by dividing the required capacity by a factor of 0.9 . So for this hybrid dryer the battery used was rated 12 V 200 Ah.

\subsubsection{The control panel}

The control panel is simply the unit that controls the system and maintains constant temperature in the drying chamber. It contains the following;

$>\quad$ On and off switch.

$>$ Signal light.

$>$ Thermostat (thermocouple)

\subsection{Performance Evaluation of the Hybrid Dryer}

The following materials were used for the testing of the hybrid dryer; tomatoes, tomatoes slicer, wet and dry mercury-in-bulb thermometer, weighing balance and digital multimeter (model; DT-830B).

\subsubsection{Operation of the hybrid dryer}

The dryer was placed in the open space free from shade throughout the day and night of operation. There are two heating sources that can be used independently or complimentarily, solar collector and heating coil element. When there is abundance of sun radiation with high intensity, sun radiation falling on the glass is being absorbed by the collector plate 
painted black and transmitted into the drying chamber through the inlet window by forced convection system. This removes the moisture given out in the drying process. On the other hand, when there is drop in temperature set or there is need to continue drying in the night to dry the products to its safe level for storage or when weather condition is bad, the thermostat switch on the heater to compliment the drying process. The photovoltaic solar panels convert solar energy to electricity. The electricity generated is used to power the heater, fans and the control system and at the same time charge the battery. The battery serves as a storage bank to store charge which is used in the night or in case of bad weather.

\subsubsection{Testing of the hybrid dryer}

Two type of testing was conducted in evaluating the dryer. They are;

\section{A. Test without loading}

This is a preliminary evaluation which involves the test for determining the maximum temperatures obtainable in the dryer when it is not loaded. The parameters that were monitored in this evaluation include temperatures of the ambient air and drying chamber and the relative humidity of the ambient air and the drying chamber. The ambient temperature was taken as initial temperature and measurement was taken at 30 minutes interval.

\section{B. Test with product loaded in the dryer}

This is the test that was carried out by loading the dryer with a product in order to determine the minimum drying time obtainable to reach a desirable final moisture content of the dried product. The parameters that were monitored here include the temperature of the drying chamber and weight of loaded samples at interval of drying time (30 minutes) in order to determine the moisture loss.

\subsubsection{Determination of the power generated by the photovoltaic (PV) solar panel}

The solar panels were mounted on a horizontal stand of about $250 \mathrm{~cm}$ height in an open space very close to the dryer. They were oriented facing south and tilted at an angle of $17^{\circ}$. The panels were connected in parallel so as to get maximum output power of the panels. The output terminals of the panels were connected to the input terminals of the digital multimeter (Model: DT-830B). The knobs of the digital multimeter were set to the appropriate range, while the current and voltage readings are taken directly from the screen display at every 30 munities interval. The power generated was calculated as:

$P=I V$

Where;

$\mathrm{P}=$ Power output $(\mathrm{W})$

$\mathrm{I}=$ Current $(\mathrm{A})$

$\mathrm{V}=$ Voltage $(\mathrm{V})$

\subsubsection{Drying procedure}

The tomatoes used for this study were obtained from the Jimeta main Modern Market Yola, Adamawa State. Samples of tomatoes were sorted and selected from the lot based on firmness, colour and size uniformity. They were cleaned by washing thoroughly with tap water, rinsed with distilled water and then wiped with an absorbent paper [26]. The cleaned tomatoes were pretreated in boiling water for 2 minutes, and the water drained. The samples were then divided into three portions. Then, each portion was slice with Tomato Slicer to a thickness of $6 \mathrm{~mm}$. The first portion of the sliced tomato (4kg) was spread in a single layer on a four different wire meshes (1 $\mathrm{kg}$ on each wire mesh) and sun dried until equilibrium moisture content was achieved. The second portion $(4 \mathrm{~kg})$ was dried in the constructed hybrid dryer by using solar collector as the heating source alone and the third portion $(4 \mathrm{~kg})$ was dried by using both heating source together. One $(1 \mathrm{~kg})$ on each wire mesh tray and it was left until constant weight was achieved. The the average weight of each dry weight was taken and recorded. The thermostat in the control panel monitored and controls the temperature of the drying chamber.

\subsubsection{Determination of the efficiency of the dryer}

The efficiency of the dryer indicates the overall thermal performance of a dryer including the efficiency of a solar collector, the drying chamber and any other supplement added to the system. The efficiency of the constructed hybrid dryer was calculated by using the formula below as described by [27, 28]; 
For forced convection solar dryers that use a fan or a bowler;

$$
\eta=\frac{W L}{I A+P_{f}}
$$

For hybrid solar dryers that use a second source of energy the efficiency is calculated as;

$$
\eta=\frac{W L}{I A+P_{f}+P_{h}}
$$

Where;

$$
\begin{aligned}
& \eta=\text { efficiency of the dryer } \\
& W=\text { weight of water evaporated from the tomatoes }(\mathrm{kg}) \\
& \mathrm{I}=\text { solar radiation }\left(\mathrm{W} / \mathrm{m}^{2}\right) \\
& \mathrm{A}=\text { area of collector }\left(\mathrm{m}^{2}\right) \\
& \mathrm{L}=\text { latent heat of vaporization of water }(\mathrm{J} / \mathrm{kg}) \\
& \mathrm{P}_{\mathrm{f}}=\text { energy consumption of fan }(\mathrm{J}) \\
& \mathrm{P}_{\mathrm{h}}=\text { energy consumption of hater }(\mathrm{J})
\end{aligned}
$$

The drying rate which was the quantity of moisture removed from the tomatoes slices in a given time was computed as described by [29].

$$
\text { Drying rate }=\frac{\text { amount of moisture removed }(\mathrm{kg})}{\text { total drying time }(\mathrm{h})}
$$

\section{RESULTS AND DISCUSSION}

\subsection{Design and Construction of a Hybrid Solar-Energy Dryer}

A hybrid solar-energy dryer was designed and constructed using readily available local materials. Figure 1 and Plate 1 showed the essential features of the hybrid dryer, consisting of the solar collector, the drying cabinet, solar panels and solar battery.

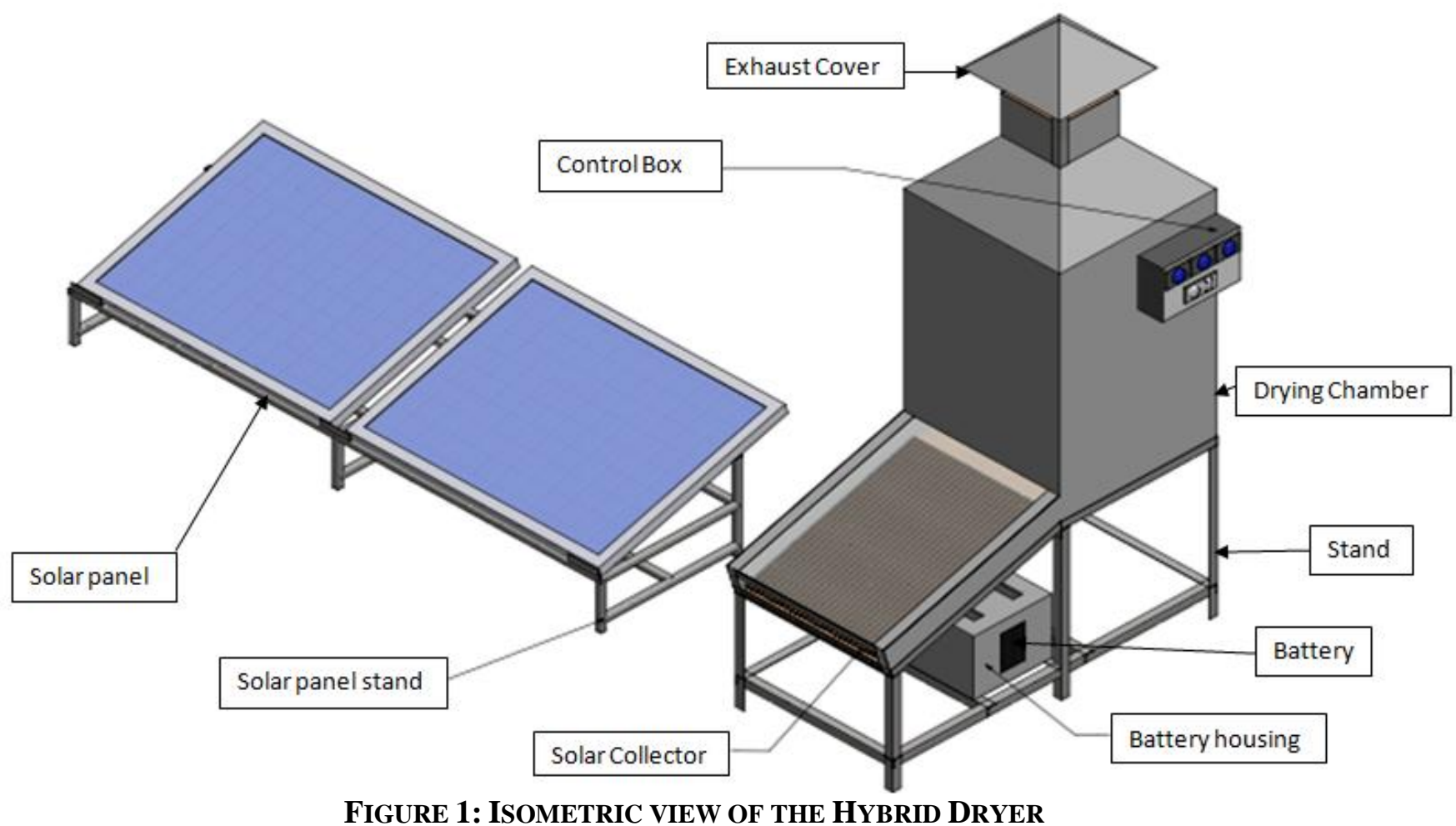




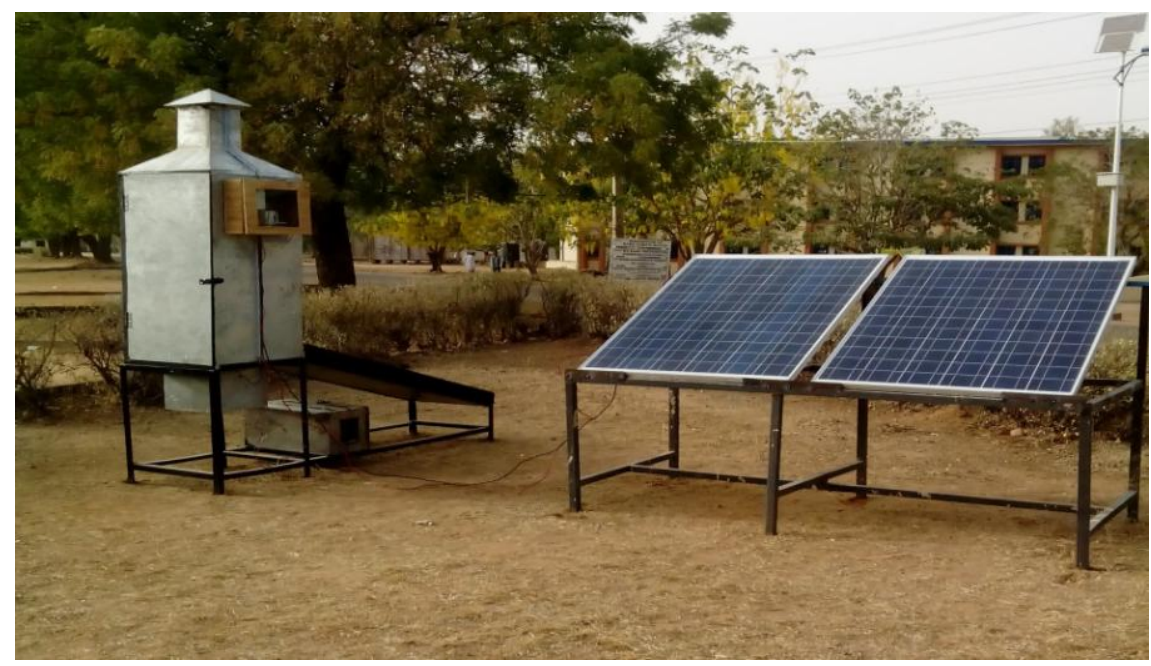

PLATE 1: FABRICATED HYBRID DRYER

\subsection{Description of the Fabricated Hybrid Dryer}

Figure 2 showed the general features of the constructed hybrid dryer.

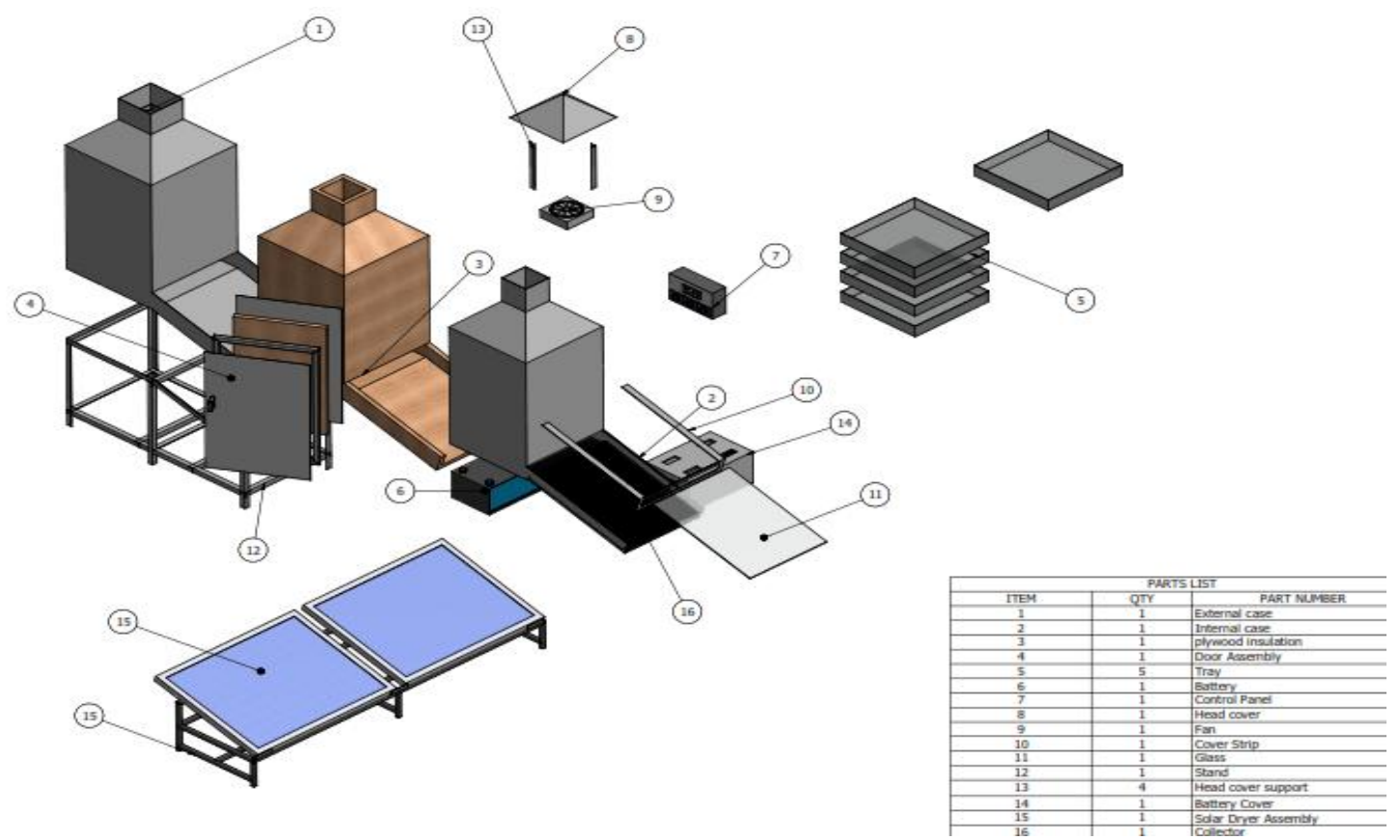

FIGURE 2: EXPLODED VIEW OF THE HYBRID DRYER

The dryer consists of an external case (1) of $600 \mathrm{~mm}$ in diameter and $1200 \mathrm{~mm}$ in height and an internal case (2) of $500 \mathrm{~mm}$ diameter and $1100 \mathrm{~mm}$ in height both are made with mild steel. The wall of the drying chamber where the drying trays (5) were located was made of plywood of $50 \mathrm{~mm}$ in thickness and build up to form a box which served as plywood insulation (3) between internal and external casing. The dryer consists of a chimney of $220 \mathrm{~mm}$ in diameter and $225 \mathrm{~mm}$ in height located on the top of the dryer chamber. Inside it was located a DC extractor fan (9) to discharge heated air and moisture from the products into the atmosphere. The top head is cover with a head cover (8) to protect the extractor fan and protect the chamber. The wall of the drying box is connected to the solar collector (16) and tilted at an angle of $17^{\circ} \mathrm{C}$ to the horizontal to give an inclination equal to the latitude of Yola $\left(7^{\circ} \mathrm{C}\right)$. The collector consists of an absorber plate made of aluminum sheet painted black and a transparent glass (11) of $5 \mathrm{~mm}$ tick which permit in only sun radiation. The absorber plate is insulated from the bottom to prevent heat losses. Air vent is provided on the lower front side of the collector for easy passage of air into the dryer it is covered with mosquito net to prevent insects into the dryer. The legs of the stand (12) are made of angle iron and tilted at an angle 17 to the horizontal at the top of the stand. The dryer also have a DC blower fan and a 500W power heater located at the bottom of the drying chamber. Two solar panel (15) with 180W power each and a battery (6) with 
200Ah power rating is use to power the system. A temperature sensor is located at the center of the chamber to sense the chamber temperature. The control box which contain on and off switch, solar regulator, and signal light.

\subsection{Performance Evaluation}

\subsubsection{Testing under unloaded condition}

This testing was carried out to determine the maximum temperature attainable in an unloaded condition of the dryer using the heating sources separately and combined. The test was carried out in five days and the results averaged. The solar collector alone was first evaluated. The test started at 7.00am on the 6th day of March 2015 when the ambient temperature was $27^{\circ} \mathrm{C}$. Figure 3 showed the changes in the temperature levels. It was observed that at $1.30 \mathrm{pm}$ the maximum average ambient temperature for the day was $45^{\circ} \mathrm{C}$, the temperature of the solar collector was $64^{\circ} \mathrm{C}$ and the drying chamber temperature was $54.9^{\circ} \mathrm{C}$. Thereafter, the chamber temperature was stable for $1 \frac{1}{2}$ hour before it started to decrease. Then it was observed that the ambient and the solar collector temperatures had fall to $44^{\circ} \mathrm{C}$ and $56^{\circ} \mathrm{C}$ respectively. This result shows that the dryer is hottest about mid-day when the sun is usually overhead, similar results were reported by [30] for a batch solar dryer under Ibadan climate, [31] for a Mixed-Mode Solar Dryer, [25] for a Small Scale Solar Dryer and [29] for a village-level solar dryer for tomato under Savanna Climate.

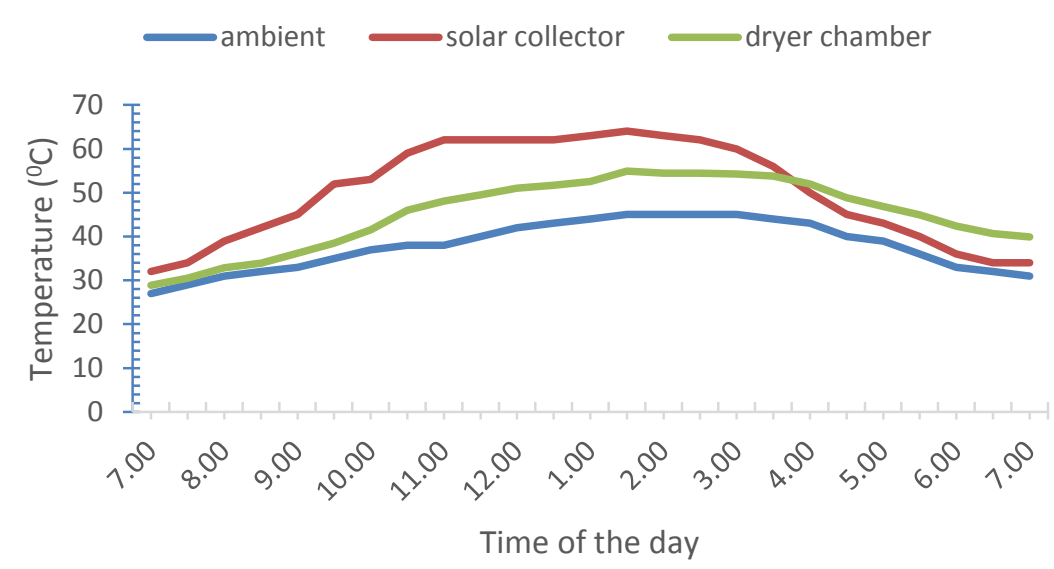

\section{Figure 3: Ambient, Solar Collector and Chamber Temperature during Solar Heating Only}

Heating with the heating element coil was also examined for 6 hours at a period when the ambient temperature has reduced. The test was carried out for three days and the results averaged. The test started at $6.00 \mathrm{pm}$ on the $10^{\text {th }}$ day of March 2015 when the ambient temperature was $34^{\circ} \mathrm{C}$ and reduces gradually to $27^{\circ} \mathrm{C}$. The graphical trend results obtained was showed in Figure 4. This shows that the chamber temperature increases irrespective of the ambient air temperature and it would require controlling the thermostat in order to control the drying chamber's temperature.

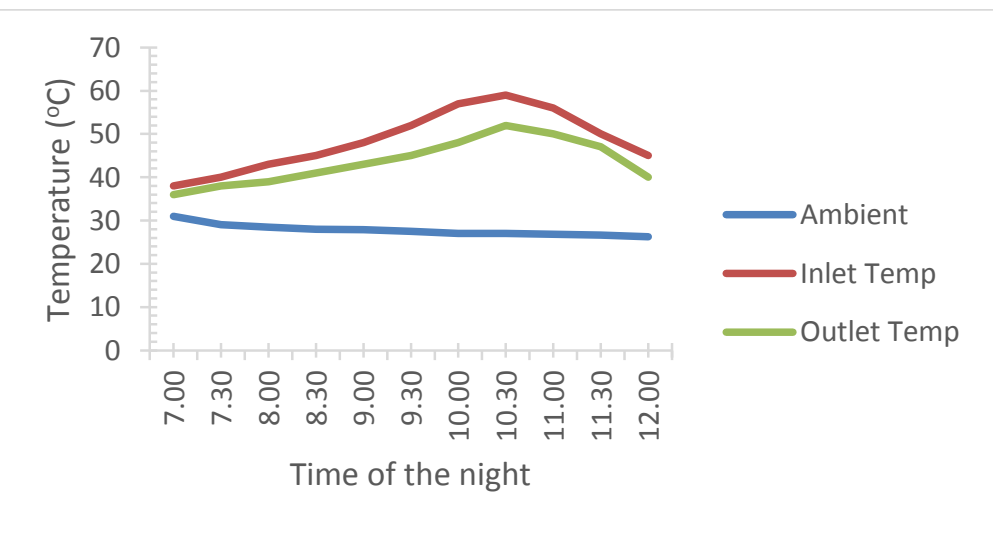

\section{Figure 4: AMbient, Drying ChAMber's InLET AND OUTLET TEMPERATURES DURING HeATING WiTH HeAting Element COIL ONLY}

On the $11^{\text {th }}$ of March, 2015 the two heating sources were combined. The test was carried out for five days and the results averaged. The test started at $6.00 \mathrm{am}$ when the ambient temperature was $28.5^{\circ} \mathrm{C}$. The evaluation started with using solar 
collector only and at the peak of the chamber temperature, the heater was introduced in order to increase the temperature. It was observed that at $1.00 \mathrm{pm}$ the maximum average ambient temperature for the day was $44^{\circ} \mathrm{C}$, the temperature of the solar collector was $72^{\circ} \mathrm{C}$ and the drying chamber temperature was $60^{\circ} \mathrm{C}$. Thereafter, the chamber temperature increased to $62.2^{\circ} \mathrm{C}$ for 1 hour before it started to decrease. Then it was observed that the ambient and the solar collector temperatures were $45^{\circ} \mathrm{C}$ and $70^{\circ} \mathrm{C}$ respectively. Figure 5 showed the temperature various level. This result was slightly higher than $56.7^{\circ} \mathrm{C}$ maximum chamber temperature reported by [15] for hybrid photovoltaic integrated greenhouse dryer and $55^{\circ} \mathrm{C}$ by [16] for forced convention photovoltaic solar dryer for the tropics. The temperatures range inside the hybrid dryer chamber was much higher than that inside the solar dryer chamber and ambient temperature during most hours of the daylight. This indicates prospect for better performance of hybrid drying method than solar and open-air sun drying methods.

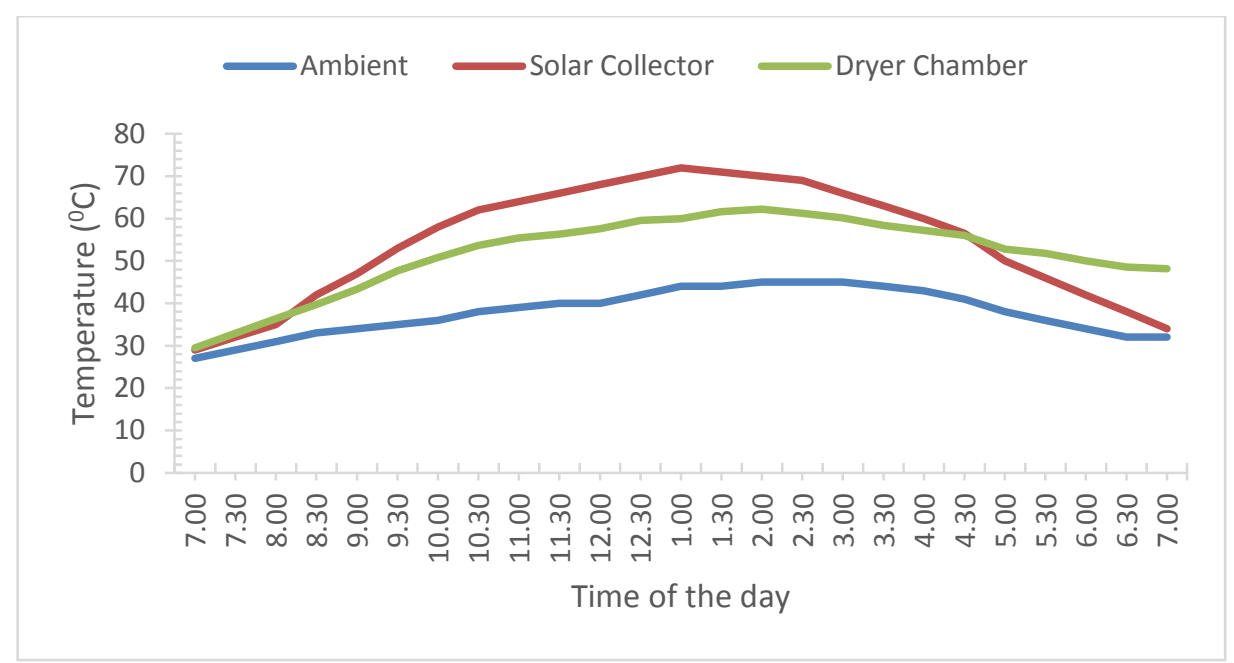

Figure 5: AMbient, SOlAR COLlECTOR AND CHAMBER TEMPERATURES DURING HYBRID HEATING

Figure 6 showed the results obtained for the diurnal variation of the relative humidity of the ambient air, solar drying chamber and hybrid drying chamber. The test was carried out in five days and the results averaged. The relative humidity of the ambient air during the testing of the dryer ranges form $51.95-92.45 \%$ while that of solar and hybrid drying method ranges from $8.22-79.03 \%$ and $5.20-79.03 \%$ respectively. This result was slightly higher than the relative humidity range $(80-87 \%)$ for ambient air and lower than the relative humidity range (11.5 - 45\%) for solar drying method obtained by [29]. This variation was observed to be due to variation in the months in which the experiment was carried out. This experiment was carried out in March/April (dry season) while their own was carried out in September/October (wet season). The power output of the panel was also determined to see if the panel can power the whole system and to test the efficiency of the panel. Figure 7 showed the graphical trend of the average results obtained for the power output of the panels. It was observed that the output power of the panel can power the hybrid drying system.

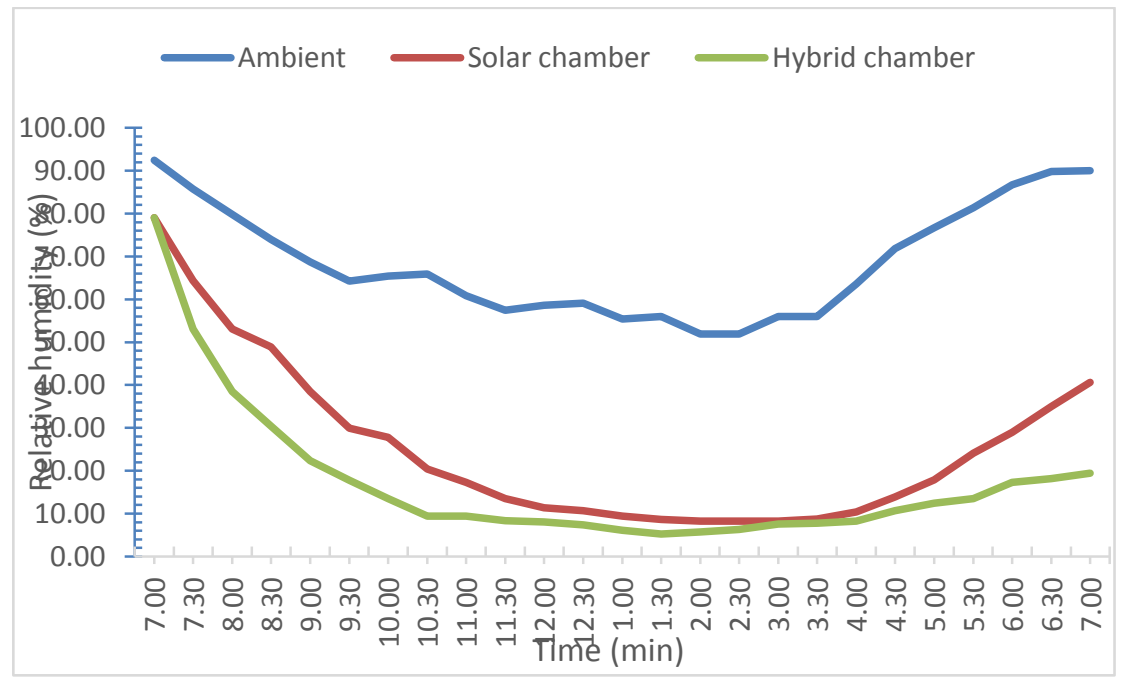

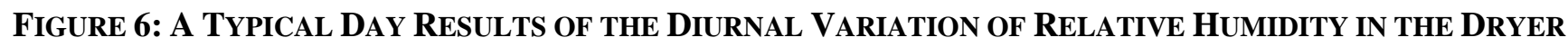




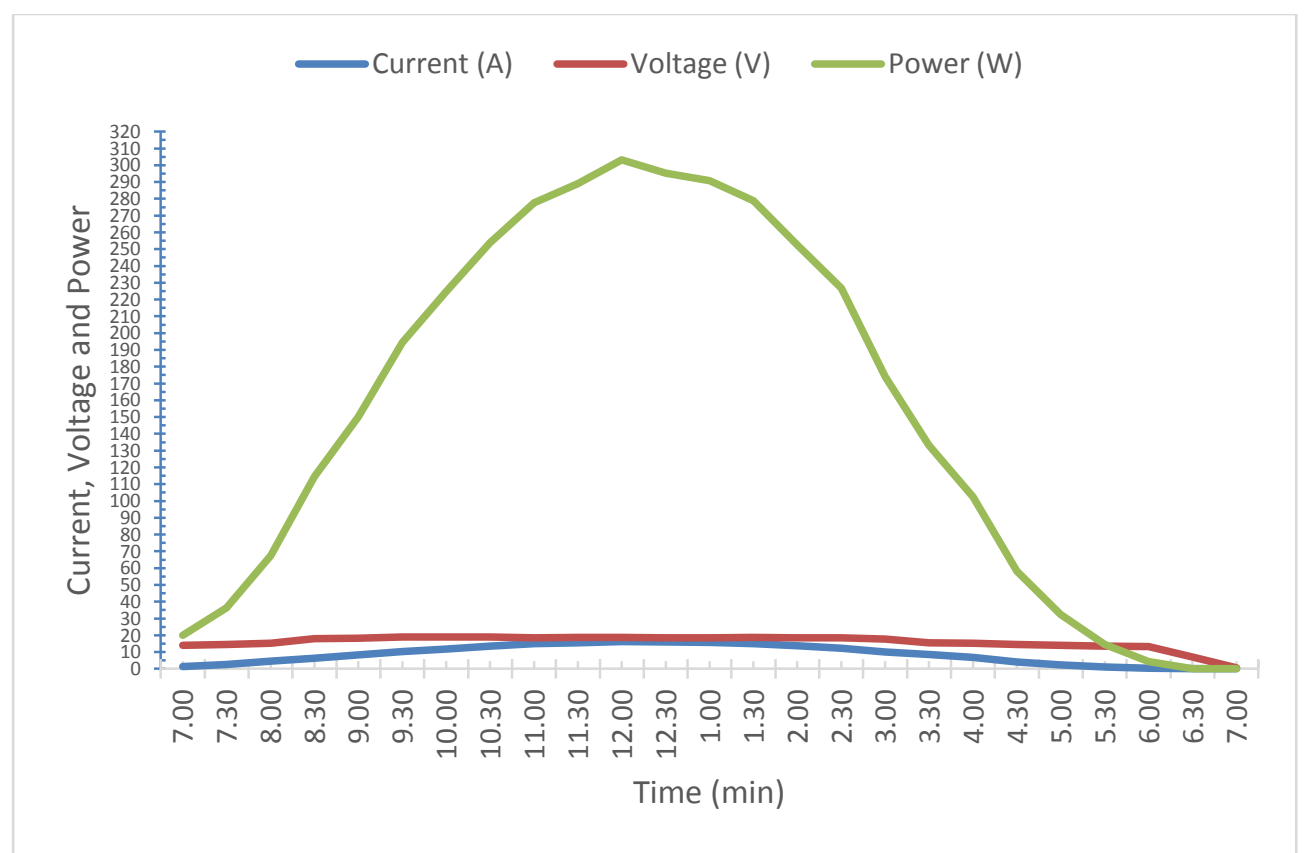

Figure 7: AVerage Result for Current, Voltage and PoWer outPut

\subsubsection{Testing under loaded condition}

This test was carried out to determine the technical viability of the dryer. The test started at $7.00 \mathrm{am}$ on the $16^{\text {th }}$ day of March 2015 when the ambient temperature was $27^{\circ} \mathrm{C}$. The initial moisture content of the tomato was determined in the laboratory using [32] AOAC (2000) air oven method and 94.22\% (wet basis) moisture content was obtained. The comparison of tomato's drying curves in the hybrid and solar method of drying with the natural open sun drying was shown in Figure 8.

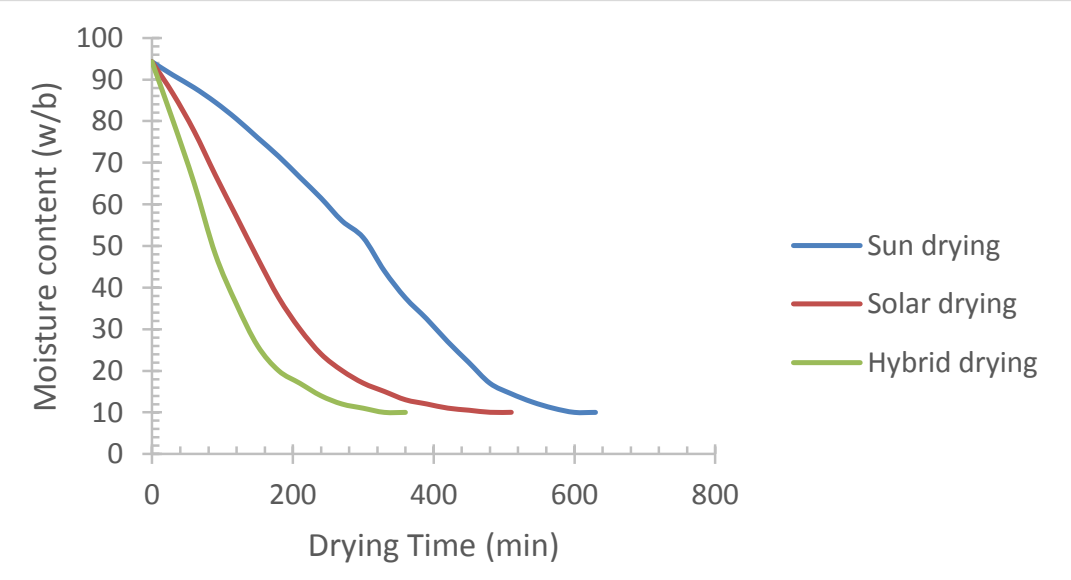

\section{FigURE 8: COMPARISON OF TOMATO'S DRYING CURVES IN THE HYBRID, SOLAR AND OPEN SUN DRYING METHODS}

Plate 2 showed the dried tomatoes in the hybrid, solar and open sun drying methods. The natural open sun drying took about $10 \frac{1}{2}$ hours to dried to equilibrium moisture content of $10 \%(\mathrm{w} / \mathrm{b})$ while the drying inside the solar dryer took $81 / 2$ hours $(20 \%$ of the time spent for the natural sun drying) and hybrid took about 6 hours (43\% of the time spent for the natural sun drying) respectively. The average drying rate and the efficiency of forced convection solar dryer was computed as $0.0578 \mathrm{~kg} / \mathrm{h}$ and $65 \%$ respectively. While hybrid was computed as $0.0800 \mathrm{~kg} / \mathrm{h}$ and $71 \%$ respectively. This result was higher than $39.6 \%$ and $0.0169 \mathrm{~kg} / \mathrm{h}$ reported by [16] for forced convention photovoltaic solar dryer for the tropics. Barnwal and Tiwari (2008) [15] reported that for a hybrid photovoltaic integrated greenhouse dryer, an overall thermal efficiency for summer and winter conditions was about 65 and $77 \%$ respectively. It was observed that the drying rate increased due to increase in temperatures thereby reducing the drying time. Similar results were reported by [25] for a Small Scale Solar Dryer and [29] for a villagelevel solar dryer for tomato under Savanna Climate. 


\section{CONCLUSION}

A hybrid solar-energy dryer using photovoltaic (PV) solar panel to power the heating element coil and charging the battery which had a storage energy system was developed, which was used to study the drying behaviour of tomato slices (result not shown). The hybrid solar-energy dryer was compared to solar and open sun drying was systems. The performance showed that the hybrid solar-energy dryer was able to generate temperatures inside the hybrid chamber to $\left(62.20^{\circ} \mathrm{C}\right)$ and the solar chamber $\left(54.90^{\circ} \mathrm{C}\right)$ and the maximum open sun drying ambient temperature was $\left(45.00^{\circ} \mathrm{C}\right)$ during most hours of the daylight. The average drying rate and the efficiency was computed to be $0.0800 \mathrm{~kg} / \mathrm{h}$ and $71 \%$ for hybrid dryer and $0.0578 \mathrm{~kg} / \mathrm{h}$ and $65 \%$ for solar-energy dryer. Good quality shelf stable dried tomato slices were produced using the hybrid drying method and which performance was influenced by effective drying time by reducing the period of the drying cycle and relatively higher drying temperature of about $62.20^{\circ} \mathrm{C}$. The temperature attained was $62.20^{\circ} \mathrm{C}$ which was suitable for drying of fruits and vegetables with vital components that are heat sensitive when dried at higher temperatures. The study has therefore provided useful information in drying process design for commodities like tomatoes which can assist in reducing post-harvest losses often incurred during harvest period of these type crops in developing economies like Nigeria. It also proved that the efficiency of agricultural dryers could be increased through the use of a combination of solar and heating element coil powered by photovoltaic (PV) solar panel, compared to conventional dryers with only solar or only biomass heating sources.

\section{REFERENCES}

[1] Ekechukwu OV and Norton B (1999). Review of solar-energy drying systems II: an overview of solar drying technology. Energy Conversion \& Management, 40: 615 - 655.

[2] Janjai S and Bala BK (2012). Solar Drying Technology, Food Engineering Review 4:16 - 54.

[3] Ajayi C, Orsunil KS and Deepak DP (2009). Design of Solar Dryer with Turbo ventilator and Fireplace. International Solar Food Processing Conference: 1-5 www.solarfood.org/solarfood/.

[4] Gutti B, Kiman, S and Mustafa BG (2012). Design and Construction of Forced/Natural Convection Solar Vegetable Dryer with Heat Storage. ARPN Journal of Engineering and Applied Sciences, 7(10): 1213 - 1217.

[5] Zhang M, Tang J, Mujumdar AS and Wang S (2006). Trends in Microwave Related Drying of Fruits and Vegetables, Trends in Food Science and Technology, 17: $524-534$.

[6] Aware R and Thorat BN (2012). Solar Drying of Fruits and Vegetables. In solar drying: Fundamentals, Applications and Innovations. (Hii CL, Ong SP, Jangam SV and Mujumdar AS Eds.), ISBN - 978-981-07-3336-0, published in Singapore, pp. 51-72.

[7] Geramitcioski, T. and Mitrevski, V. (2011). Design and construction of a new mobile solar dryer, Second International Conference on Sustainable Postharvest and Food Technologies INOPTEP 2011, Velika Plana. Pp 24 - 26.

[8] Bassey MW (1985). Design and performance of hybrid crop dryer using solar-energy and sawdust. In: Proceedings of the ISES congress INTERSOL 85, Montreal, Canada, Oxford: Pergamon Press, 1038-1042.

[9] Babarinsa FA, Williams JO and Ngoddy PN (2006). Development of a Hybrid Dryer with Kerosene and Solar Heat Source. Nigeria Drying Symposium series, 2: 27 - 34.

[10] Prasad J and Vijay VK (2005). Experimental studies on drying of Zingiber officinale, Curcuma longa L. and Tinospora cordifolia in solar-biomass hybrid dryer. Renew Energy 30:2097-109.

[11] Amer BM., Hossai, MA and Gottschalk K (2010). Design and performance evaluation of a new hybrid solar dryer for banana, Energy Conversion and management 51: 813-820.

[12] Boughali S, Benmoussa H, Bouchekima B, Mennouche D and Bouguettaia H (2009) Crop drying by indirect active hybrid-solarelectrical dryer in the eastern Algerian Septentrional Sahrta. Solar Energy 83: 2223-2232.

[13] Reyes A, Mahn A, Huenulaf P and González T (2014) Tomato Dehydration in a Hybrid-Solar Dryer. Journal Chemical Engineering Process Technology 5 (4): $1-8$.

[14] Saleh T and Sarkar MAR (2002). Performance Study of A PV Operated. Forced convection solar energy dryer. A paper accepted for presentation at the technical session of the 8th International Symposium for Renewable Energy Education (ISREE-8), August 4-8, to be held at Orlando. University of Florida, USA (http://www.doce-conferences.ufl.edulisree8/papers.asp and $h t t p:$ //www. fsec. ucf eduledliasee/isreel sarkar -dryer. pdf).

[15] Barnwal P and Tiwari A (2008). Design, Construction and Testing of Hybrid Photovoltaic Integrated Greenhouse Dryer, International Journal of Agricultural Research 3 (2): 110-120.

[16] Adelaja AO and Ojolo SJ (2010). Design, Analysis and Experimental Evaluation of Photovoltaic Forced Convection Solar Dryer for the Tropics. International Journal of Engineering Research in Africa, 3: 49 - 61.

[17] Ehiem JC, Irtwange SV and Obetta SE (2009). Design and Development of Industrial Fruits and Vegetable Dryer. Journal of Applied Science, Engineering and Technology, 1(2): 44 - 53.

[18] Adzimah KS and Seckley E (2009). Improvement on the design of a cabinet grain dryer. American Journal of Engineering and Applied Science, 2(1): 217 - 228.

[19] Holman JP (1998). Heat Transfer. 9th Edn., McGraw Hill, New York. 
[20] EL- Amin OMA, Mohamed AI, El-Fadil AA and Luecke W (2005). Design and Construction of a Solar Dryer for Mango Slices. Department of Agricultural Engineering, University of Zalinga, Sudan.

[21] Brenndorfer B, Kennedy L, Bateman COO, Mrema GC and Wereko-Brobby C (1985). Solar dryers their role in postharvest processing. London: Commonwealth Science Council (Commonwealth Secretariat Publications), 1985.

[22] Medugu DW and Yakubu D (2011). Estimation of mean monthly global solar radiation in Yola - Nigeria using angstrom model. Advances in Applied Science Research, 2011, 2 (2): 414 - 421.

[23] Bukola OB (2008). Design and Performance Evaluation of a Solar Poultry Egg Incubator. Thammasat International Journal of Science and Technology, 13(1): $47-54$.

[24] Adegoke CO and Bolaji BO (2000). Performance evaluation of solar-operated thermo siphon hot water system in Akure. International Journal of Technology, 2(1): 35 - 40.

[25] Onigbogi IO, Sobowale SS and Ezekoma OS (2012). Design, Construction and Evaluation of a Small Scale Solar Dryer. Journal of Engineering and Applied Science, 4: 8 - 21.

[26] Owusu J, Haile M, Zhenbin W and Agnes A (2012). Effect of Drying Methods on Physicochemical Properties of Pre-treated Tomato (lycopersicon esculentum mill.) Slices. Croatian Journal of Food Technology, Biotechnology and Nutrition 7 (1-2): 106 - 111.

[27] Augustus LM, Kumar S and Bhattacharya SC (2002). A comprehensive procedure for performance evaluation of solar food dryers, Renewable and Sustainable Energy Reviews, 6 (4), 367-393.

[28] Bennamoun L (2012). An Overview on Application of Exergy and Energy for Determination of Solar Drying Efficiency, International Journal of Energy Engineering 2(5): 184 - 194.

[29] Aliyu B, Kabri HU and Pembi PD (2013). Performance evaluation of a village-level solar dryer for tomato under Savanna Climate: Yola, Northeastern Nigeria, Agric Eng Int: CIGR Journal 15(1): 181 - 186.

[30] Adejumo AOD and Bamgboye AI (2004). Development and evaluation of a batch solar dryer under Ibadan climate. Proceeding Nigerian Institution of Agricultural Engineers, 26: 412-423.

[31] Olalusi AP and Bolaji BO (2008). Performance Evaluation of a Mixed-Mode Solar Dryer, AU J.T. 11(4): 225-231.

[32] AOAC (2000). Official Methods of Analysis of the Association of Official Analytical Chemists. 17 editions. AOAC International, Maryland. 